\title{
Land Evaluation for Land Use Planning Using Remote Sensing and GIS \\ - A Case Study of Nawagaon Maskara Rao Watershed, Saharanpur, India
}

\section{Adegbenro R0 ${ }^{1 *}$, Suresh Kumar ${ }^{2}$, Justin K George ${ }^{2}$, Ojetade $\mathrm{JO}^{1}$ and Amusan AA ${ }^{1}$}

${ }^{1}$ Department of Soil Science and Land Resources Management, Obafemi Awolowo University, Ile-Ife, Nigeria

${ }^{2}$ Indian Institute of Remote Sensing, Dehradun, Uttarakhand, India

*Corresponding Author: Adegbenro RO, Department of Soil Science and Land Resources Management, Obafemi Awolowo University, Ile-Ife, Nigeria.

DOI: 10.31080/ASAG.2020.04.0784
Received: December 16, 2019

Published: January 28, 2020

(C) All rights are reserved by Adegbenro

RO., et al.

\begin{abstract}
The study was conducted using existing soil data from Nawagaon and Maskara Rao watershed boundary in Shaharanpur district, India to assess land capability classes using Remote Sensing and GIS approach. Land sat image was integrated with SRTM DEM for delineation of landforms and analysis of land use/land cover data. The filled SRTM DEM of the study area was extracted at $30 \mathrm{~m}$ resolution to extract terrain parameters such as elevation, slope and aspect. SRTM DEM was visually interpreted. Three major landforms were identified, namely, 3 landforms - hills, piedmont plains and alluvia plains. These were further delineated according to slope and finally according to vegetation cover to give eight physiographic units. The slope map and aspect map were produced using filed Dem and were classified into nine and two classes respectively. Land use/land cover map was also generated using satellite image for the study area in India. The dominant land use was: dense forest, degraded forest, crop land I, crop land II, scrub/barren, settlement, river, canal and road.

Based on the slope map, land characteristics of each physiographic unit and land capability criteria for land qualities, land capability classes were assigned and were translated into a land capability map. The soils were placed in seven classes (I, II, III, IV, VI, VII and VIII). Both the GIS approach and LCC evaluation using criteria rating of FAO gave the same classes for the mapped soil. The study revealed that soils from the study areas varied with different physiographic unit, therefore soils of the hilly areas should be put to use for nature conservation other than arable production while the lower portion should be cultivated with intensive care for arable crops.
\end{abstract}

Keywords: SRTM DEM; Landsat; Physiography; Land Use/Land Cover; Land Evaluation

\section{Introduction}

Land is one of the most important natural resources, which plays an important role in the economic life of a majority of people in the world. Land is a limited resource and with increasing population, the demands for land become more competitive. Any given area of land can have a multiple of potential uses and may need to be considered in planning land resources. Soil is also a product of interactions among parent material, relief, climate, organisms over a period of time. It covers most lands of the earth, but regarding its service for humans, soil is a limited and largely non-renewable resource [3]. Therefore, any serious attempt to use land judiciously for agriculture, engineering, urban development, pollution control, e. t. c., must start with the knowledge of the nature, type, and spatial distribution of soils existing in the regions as produced in land resource surveys [7]. 
Land evaluation is of great important for making decision on sustainable land use. The term "Land suitability assessment" refers to the investigation of a certain part of land's appropriateness to a specific type of land use [1]. This assessment involves many factors that directly or indirectly control the ability of this part of land to host the land use under investigation. The main object of the land suitability evaluation is the prediction of potential capacity of the land unit for a given use without deterioration [4]. However, the potential of the land for crop production to satisfy the demand of the ever increasing population is declining as a result of severe soil degradation [5]. Land evaluation takes into account the physical nature of the land (e.g. geology, soils and slope) plus other factors (climate, erosion hazard, land management) which determine how that land can be use without destroying its long-term potential for sustainable production.

Good land management needs reliable information about land qualities. These complex attributes of land are divided from simpler, directly measurable properties obtained from natural resource survey. Satellite based remote sensing data has emerged to be a vital tool in soil resource survey and generation of information which help to evolve the optimum land use plan for sustainable development of the area. The task of gathering information on the soils has been greatly synergized by the enhanced speed and reliability with spatial and temporary information is generated in by remote sensing techniques in a cost effective manner. The use of digital data sources, such as digital elevation models (DEM) and Landsat satellite data can speed up the completion of digital databases and improve the overall quality, consistency and reliability of the database. Traditionally, landform delineations were carried out using aerial photography. With the increasing availability of digital elevation model (DEM), a surface is characterized by attributes such as elevation, slope, aspect, plan and profile curvature, and flow accumulation to obtain relief or surface topography units [6], and these provide greater functionalities than the qualitative and nominal characterization of topography [2].

GIS has been found to be the best tool for performing numerous spatial analyses, including overlaying combinations of features and recording resultant conditions, analyzing flows or other characteristics of network. Its uses in various fields include facility management, planning, agricultural development, environmental monitoring e. t. c. This study was carrying out using combination of remote Sensing and Geographic Information System (GIS) with attribute data for land evaluation.

The objectives of this study were to prepare physiographic soil map and land use and land cover (LULC) map at 1:50,000 scale using Landsat TM data, analyze terrain characteristics using SRTM DEM and generate Land Capability map for land use planning.

\section{Materials and Methodology}

\section{General description of the study areas}

The study in India area covers Nawagaon and Maskara Rao watershed boundary, a part of Saharanpur, Uttar Pradesh district and District in Northern state in India which lies between latitude $30 \mathrm{o}$ $09^{\prime} 00^{\prime \prime} \mathrm{N}$ to 30 o $21^{\prime} 00$ " $\mathrm{N}$ and longitude between 77o $36^{\prime} 00^{\prime \prime} \mathrm{N}$ to $77 \mathrm{o} 45^{\prime} 00^{\prime \prime} \mathrm{N}$ (Figure 1a) with an altitude ranging from 295 $860 \mathrm{~m}$ (ASL) covering an area of 13663.27 hectares. The area qualifies for semi-arid monsoon climate with distinct summer, winter and rainy seasons. It experiences mean annual rainfall of $1170 \mathrm{~mm}$. The mean annual temperature is $23.3^{\circ} \mathrm{C}$ with a mean summer temperature of $29.4^{\circ} \mathrm{C}$ and mean winter temperature of $15.1^{\circ} \mathrm{C}$. The highest percentage of humidity $72-85 \%$ is found during the rainy season at the lower range of humidity between $29-51.5 \%$ is recorded in the summers. Physiography of the area varies from plain area until hilly, since the study area is a part of southern slope of Shiwalik Hill, the denudational, colluvial and alluvial process form Physiography of the area. The entire area is divided into 3 general system of landform: Shiwalik Hills, Piedmont and Alluvial plain. The soils are mostly alfisols, entisols and inceptisols. The soil moisture regime has been computed as ustic and temperature regime as hypothermic. The major land use of the study area is forest (open forest and dense forest), plantation (mango orchard), agricultural crops (wheat), scrub (barren land, fallow land and river bed), and settlement (habitation). Mostly wheat in rabi season, and in the kharif season paddy and sugarcane are grown.

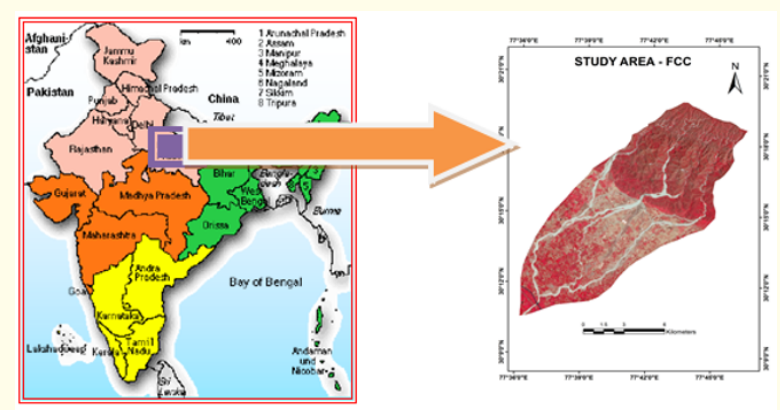

Figure 1: A: Location of the study area in India.

Data used

This study was carried out using existing data from India. This includes the following:

- $\quad$ LANDSAT 8- April $17^{\text {th }}$ and May $3^{\text {rd }} 2015$ (Stacked)

- DEM-SRTM 30m

The satellite data were georeferenced using WGS 84 datum, Universal Transverse Mercator (UTM) zone 44N projection in Arc- 
GIS desktop 10.1. Both DEM and LANDSAT were generated with a cell size of $30 \mathrm{~m}$ and finally used for the study. The delineation of landforms was done using on screen image visual interpretation techniques. Geomorphic features were interpreted bases on key image elements such as shape, tone, colour, pattern, shadow and texture. Different band combinations of satellite data were used to generate a false colour composite (FCC) for image interpretation and on screen mapping. Visual image interpretation and digital image analysis and land capability classification was conducted using ERDAS 9.2 and ArcGIS10.1

\section{Physiographic map}

Boundary map was made considering the satellite imageries in delineating the study area logically with the help of image features e.g. tone, texture, pattern, shape, landform, slope and elevation.

\section{Land use/Land cover map}

The satellite images were interpreted individually for the detailed information about land use activities and land cover. To generate the land use land cover map, the geometric corrected Landsat image was used. This satellite image was interpreted making use of the interpretation keys. This helped for making visual interpreted Lu/Lc map.

\section{DEM}

Digital Elevation Model was extracted from SRTM DEM with a cell of $30 \mathrm{~m}$ and was filled for terrain analysis.

\section{Slope map}

Terrain data was analyzed as a component in complex GIS modeling. Slope is expressed as the change in elevation over a certain distance. It is the maximum change in Z-value. In this case the certain distance is the size of the pixel. The maximum change in eleva- tion over the distance between the cell and its neighbor identifies the steepest downhill descent from the cell. The lower the slope value, the flatter the terrain; the higher the slope value, the steeper the terrain. Slope is most often expressed as a percentage, but can also be calculated in degrees. Slope map was generated in ARC GIS software using SRTM DEM and was being color-coded according to the steepness of the terrain at each pixel.

\section{Aspect Map}

An aspect map shows to which side the slope is directed. An aspect value of 0 means that the slope is facing North. The aspect of a slope can make very significant influences on the local conditions and temperature. It can be used to calculate the solar illumination for each location in a region as a part of study to determine diversity of life at each side. It is measured clockwise in degrees from 0 (due north) to 360 (due north), coming full circle. The flat areas having no downslope value are given a value of -1 .

\section{Creation of Soil data base}

After creating the physiographic map and preparing its legends, the soil database was created. By inserting soil depth, Texture, Drainage, Coarse fragment and erosion column in the soil table, thematic maps were created using the physiographic map, soil table and the corresponding column.

\section{Land capability classification}

Land capability classification involves an evaluation of the degree of limitation posed by permanent or semi-permanent attributes of land to one or more land use. It is essentially a negative approach whereby the degree of constraint increases, the capability of land decreases. By combining the slope map, physiographic soil map and land capability criteria, land have been classified according to its capability (Table 1).

\begin{tabular}{|l|c|c|c|c|c|c|c|c|}
\hline Characteristics & \multicolumn{9}{|c|}{ Classes } \\
\hline & I & II & III & IV & V & VI & VII & VIII \\
\hline Topography (e) & & & & & & & & \\
\hline Slope & $0-1$ & $1-3,3-5$ & $5-10$ & $10-15,15-25$ & $0-1$ & $25-33$ & $33-50$ & $>50$ \\
\hline Erosion & e0 & e1 & e2 & e3 & e0 & e3 & e3 & e4 \\
\hline Flooding & Nil & Nil & Nil-slight & Slight-moderate & Moderate-severe & Nil-severe & Nil-severe & - \\
\hline Drainage & Well & Mod-well & Imperfect & Poor & V. Poor & Somewhat & Excessive & Excessive \\
\hline Soil Physical Condition & & & & & & & & \\
\hline Depth & $>150$ & $150-100$ & $100-50$ & $50-25$ & $25-10$ & $<10$ & $<10$ & \\
\hline $\begin{array}{l}\text { Texture } \\
\text { L, CL }\end{array}$ & $\begin{array}{c}\text { SiCL, CL, SL, } \\
\text { SCL, Sil }\end{array}$ & LS, SC, SiC & Coarse sand & - & - & - & - \\
\hline $\begin{array}{l}\text { Surface coarse frag- } \\
\text { ment }\end{array}$ & $1-3$ & $3-15$ & $15-40$ & $40-75$ & $15-75$ & $75+$ & - & - \\
\hline $\begin{array}{l}\text { Subsurface coarse } \\
\text { fragment }\end{array}$ & $<15$ & $<15$ & $15-35$ & $35-50$ & $50-75$ & $50-75$ & $55-90$ & $>75$ \\
\hline
\end{tabular}

Table 1: Criteria for Land capability classification.

Depth (in cms): Very shallow: 10-25; Shallow: 25-50; Mod. Deep: 50-100; Mod. Deep: 50-100; Deep: 100-150; V. Deep: >150; V. Deep: $>150$ V. Deep: >150; Texture: Csl=coarse sandy loam; $\mathrm{Sl}=$ sandy loam; Sil= silt; Coarse fragment: Slight (s)=0-15\%; Moderate (M)=5-

$35 \%$; severe $(S)=35-50 \%$; very severe $(V s)=>50 \%$; Drainage: Excessive $=>100$; well=75-100; moderate=50-75; poor $=25-50$; very poor $=0-25$. 


\section{Results and Discussion}

Land use/Land cover

The satellite imagery (figure $1 \mathrm{~b}$ ) was interpreted for the detailed information about land use activities and land cover. The interpretation was done making use of the interpretation keys. This interpretation helped for making visual interpreted of Lu/Lc Map. The study area was divided into nine broad land use classes; these are dense forest, degraded forest, crop land I, cropland II, scrub/ barren, settlement, river, road and canal (Figure 2 and Table 2).

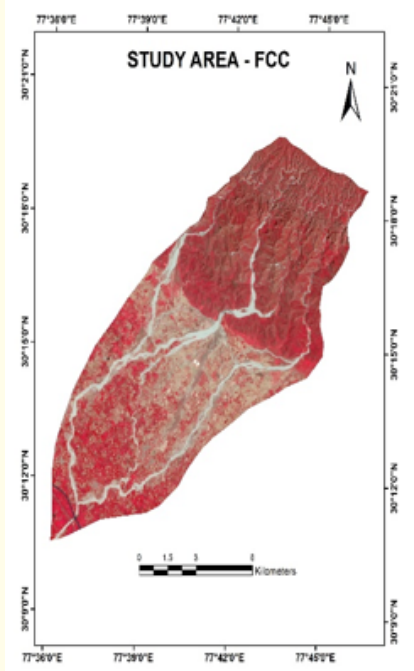

Figure 1: B. Study area FCC.

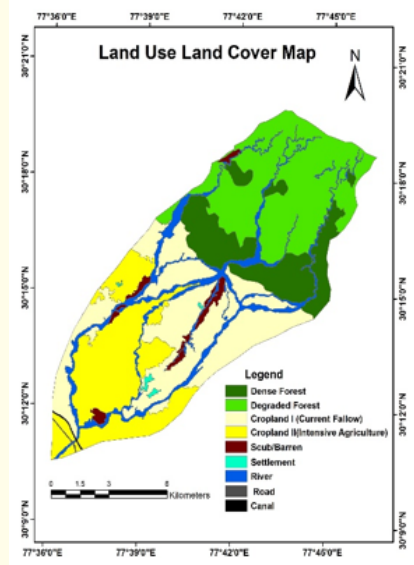

Figure 2: LULC Map.

\begin{tabular}{|l|c|c|}
\hline LULC & Area (ha) & Area (\%) \\
\hline Dense forest & 1901.20 & 13.85 \\
\hline Degraded forest & 3599.71 & 26.21 \\
\hline Crop land 1 & 3647.09 & 26.56 \\
\hline Cropland 11 & 2917.47 & 21.25 \\
\hline Scrub/barren & 263.46 & 1.92 \\
\hline Settlement & 41.05 & 0.30 \\
\hline River & 1335.46 & 9.73 \\
\hline Road & 9.97 & 0.07 \\
\hline Canal & 16.75 & 0.12 \\
\hline Total & 13732.16 & 100 \\
\hline
\end{tabular}

Table 2: LULC distribution.

\section{Digital Elevation model}

A digital elevation model (DEM) is a digital model or 3D representation of a terrain surface. It consists of a sampled array of elevation for a number of ground positions at regularly spaced intervals. The elevation of the study area varied in the range of $295 \mathrm{~m}$ to $860 \mathrm{~m}$ above the mean sea level (amsl) as represented in the figure 3.

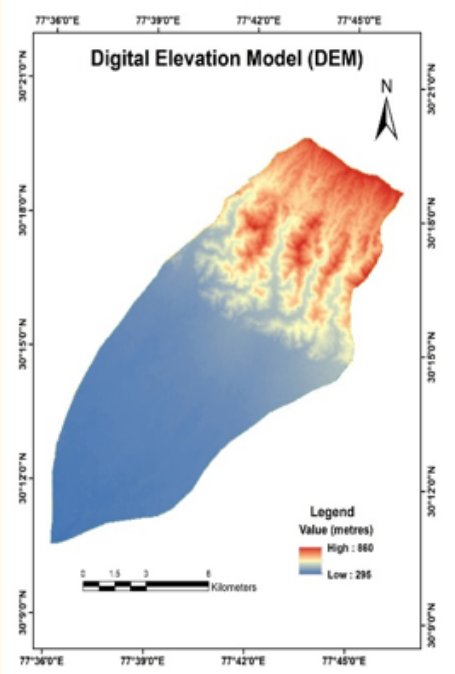

Figure 3: Digital Elevation Model (DEM).

\section{Aspect}

The aspect map was prepared form filled SRTM DEM in figure 3. Various types of aspect are found in the study areas, but aspects 
was divided in two categories that are north aspect and south aspect. The figure 4 below showed that $58.66 \%$ aspect tends to south while $41.35 \%$ of the aspect tends to North.

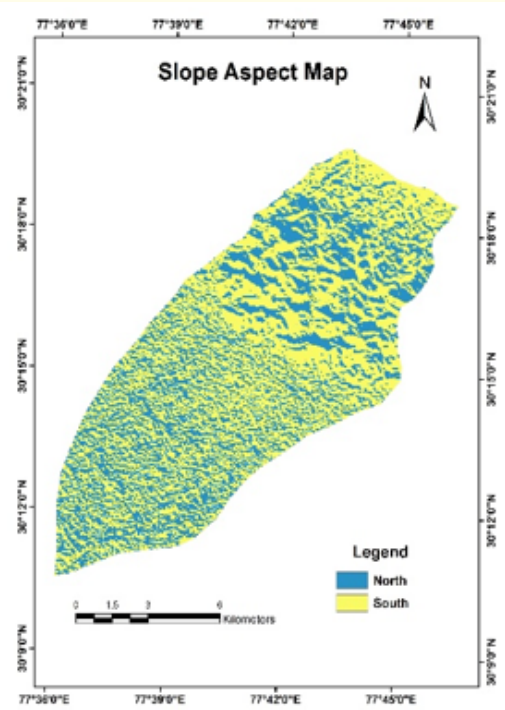

Figure 4: Slope Aspect map.

\section{Slope map}

The slope map was prepared from filled SRTM DEM figure 3. The study area was divided into nine slope classes in figure 5 and table 3. These are: nearly level (0-1\%), very gentle sloping (1-3\%), gentle sloping (3-5\%), moderately sloping (5-10\%), strongly sloping $(10-15 \%)$, moderately steep to steep (15-25\%), steep (25$33 \%)$, very steep(33-50\%) and very very steep $(>50 \%)$.

\begin{tabular}{|l|c|}
\hline Slope\% & Area (ha) \\
\hline 1 & 382.77 \\
\hline 2 & 3207.15 \\
\hline 3 & 3347.1 \\
\hline 4 & 1307.25 \\
\hline 5 & 555.75 \\
\hline 6 & 1807.74 \\
\hline 7 & 1301.31 \\
\hline 8 & 1484.32 \\
\hline 9 & 468 \\
\hline Total & 13860.63 \\
\hline
\end{tabular}

Table 3: Slope distribution.

Physiography soil map

The satellite image (figure 1) was interpreted for the detailed information about land use activities and land cover. This was carried out using interpretation keys. This interpretation helped for making visual interpreted of LULC map. The study area was delineated into 3 landforms - hills, piedmont plains and alluvia plains. The three landforms were further delineated according to slope and finally according to vegetation cover to give 8 physiographic units in figure 6 and table 4.

General characteristics of soil composition of the study area in India

There were five types of soil found in the study area - coarse sandy loam, sandy loam, loamy sand, sandy clay loam and silt loam

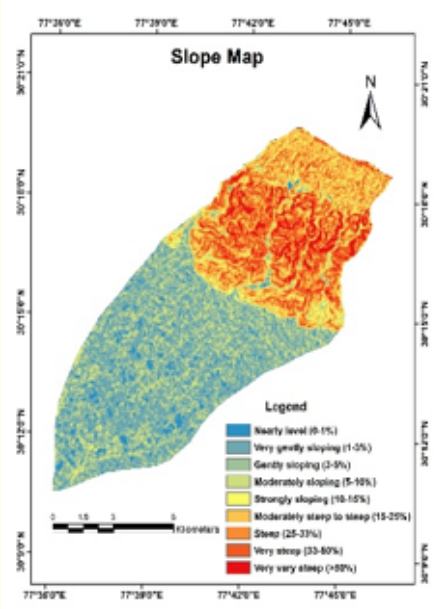

Figure 5: Slope map.

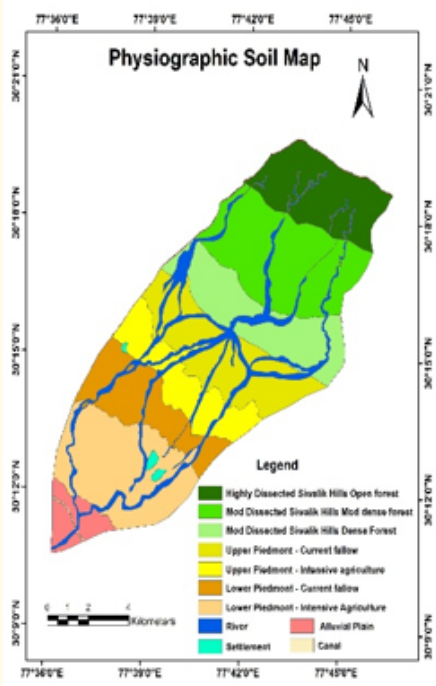

Figure 6: Physiographic Soil Map. 


\begin{tabular}{|l|c|c|c|}
\hline Map unit & Physiographic & Area(ha) & $\begin{array}{c}\text { Total \% } \\
\text { Area }\end{array}$ \\
\hline H11 & $\begin{array}{c}\text { Highly dissected siwalik } \\
\text { hills open forest }\end{array}$ & 1612.02 & 11.80 \\
\hline H12 & $\begin{array}{c}\text { Moderate dissected siwa- } \\
\text { lik hills moderate forest }\end{array}$ & 2416.55 & 17.69 \\
\hline H13 & $\begin{array}{c}\text { Moderate dissected siwa- } \\
\text { lik hills dense forest }\end{array}$ & 1573.76 & 11.52 \\
\hline UP11 & $\begin{array}{c}\text { Upper piedmont-current } \\
\text { fallow }\end{array}$ & 1615.67 & 11.83 \\
\hline UP12 & $\begin{array}{c}\text { Upper piedmont-intensive } \\
\text { agriculture }\end{array}$ & 1133.67 & 8.30 \\
\hline LP11 & $\begin{array}{c}\text { Lower piedmont-current } \\
\text { fallow }\end{array}$ & 1267.81 & 9.28 \\
\hline LP12 & $\begin{array}{c}\text { Lower piedmont-intensive } \\
\text { agriculture }\end{array}$ & 2104.17 & 15.40 \\
\hline River & & 1416.58 & 10.37 \\
\hline Settlement & & 58.82 & 0.43 \\
\hline Alluvial & & 451.37 & 3.30 \\
\hline Canal & & 12.84 & 0.09 \\
\hline Total & & 13663.26 & 100 \\
\hline
\end{tabular}

as shown in Table 5 below. The hilly areas had coarse sandy loam soils and loamy sand, while the piedmont plains had coarse sandy loam, sandy loam, loam and silt loam soils; the hilly areas had very shallow to moderate soil depth, while piedmont plains and alluvial had very deep soils; coarse fragment in hilly areas was very severe or severe, while in piedmont plains it was moderate or severe and in the alluvial plains, it was slight; drainage in the hilly areas was on an excessive, while in the piedmont plains it was well and in the alluvial drainage was well.

Land capability classification of soils in India

Land capability classes for study area were summarized in Table 6 to 13 and in figure 7 to 13. It was found that in hilly areas, land had severe limitations (Class VIII) and soil and water conservation techniques are more difficult to apply; in piedmont plains, land had moderate limitations (Class II - IV), which limited the choice of crops but conservation techniques can be applied; the alluvial plain also had low limitations (II) compare to other part of the physiographic units.

Table 4: Physiographic distribution.

\begin{tabular}{|l|c|c|c|c|c|}
\hline Physiography unit & Texture & Depth & Coarse fragment \% & Drainage & Erosion hazard \\
\hline H11 & Ls & Vs & $>60$ & Excessive & e4 \\
\hline H12 & CSl & Sh & $50-60$ & Excessive & e4 \\
\hline H13 & CSl & Md & $40-50$ & Excessive & e3 \\
\hline PII & CSl & Md & $30-40$ & Well & e3 \\
\hline P12 & Sl & D & $10-15$ & Well & e2 \\
\hline P21 & L & Vd & 5 & Well & e1 \\
\hline P22 & L & Vd & $1-3$ & Well & e1 \\
\hline Alluvial & Sil/SCl & Vd & $1-3$ & Well & e1 \\
\hline
\end{tabular}

Table 5: Land qualities of the soils in India.

\begin{tabular}{|l|c|c|c|c|c|c|}
\hline Map unit & Depth & Texture & Erosion class & Drainage & Coarse-frag\% & LCC \\
\hline H11 & VI & III & VIII & VI & V & VIII \\
\hline H12 & IV & II & VIII & VI & V & VIII \\
\hline H13 & III & II & IV & VI & IV & VI \\
\hline PII & III & II & IV & I & III & IV \\
\hline P12 & II & II & III & I & II & III \\
\hline P21 & I & I & II & I & II & II \\
\hline P22 & I & I & II & I & I & II \\
\hline Alluvial & I & I & II & I & I & II \\
\hline
\end{tabular}

Table 6: Land capability classification for soils in India. 


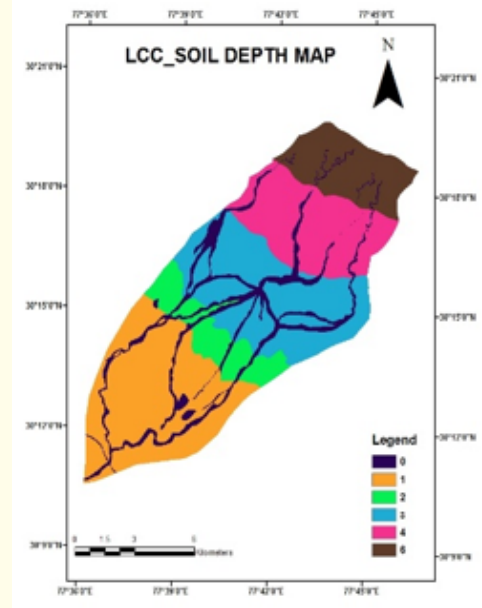

Figure 7: LCC_Soil Depth Map.

\begin{tabular}{|l|c|c|}
\hline Depth & Area (ha) & Area (\%) \\
\hline Miscellaneous & 1484.37 & 10.86487436 \\
\hline 1 & 3823.03 & 27.98274057 \\
\hline 2 & 1134.36 & 8.302969529 \\
\hline 3 & 3191.04 & 23.35687779 \\
\hline 4 & 2415.78 & 17.68234752 \\
\hline 6 & 1613.52 & 11.81019023 \\
\hline Total & 13662.1 & 100 \\
\hline
\end{tabular}

Table 7: LCC_Soil depth distribution.

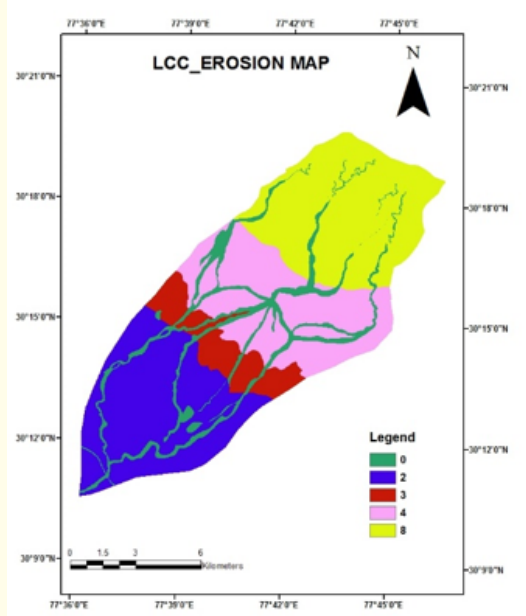

Figure 8: LCC_Erosion Status Map.

\begin{tabular}{|l|c|c|}
\hline LCC_Erosion & Area (ha) & Area (\%) \\
\hline miscellaneous & 1484.37 & 10.86487 \\
\hline 2 & 3823.02 & 27.98267 \\
\hline 3 & 1134.36 & 8.30297 \\
\hline 4 & 3191.04 & 23.35688 \\
\hline 8 & 4029.3 & 29.49254 \\
\hline Total & 13662.09 & 100 \\
\hline
\end{tabular}

Table 8: LCC_Erosion Status distribution.

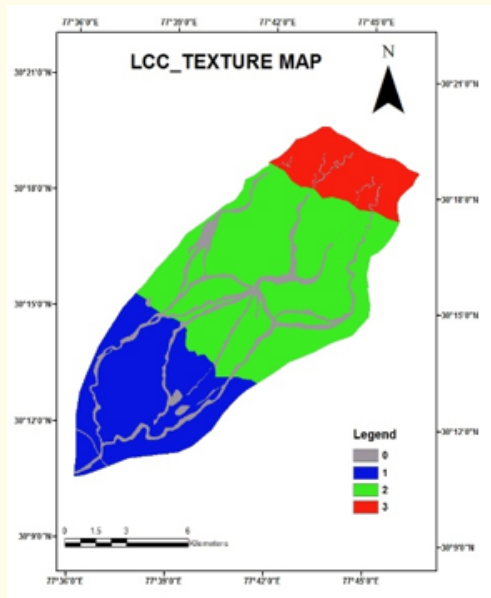

Figure 9: LCC_Surface Texture Map.

\begin{tabular}{|l|c|c|}
\hline LCC_Texture & Area (ha) & Area (\%) \\
\hline Miscellaneous & 1484.37 & 10.86487 \\
\hline 1 & 3823.02 & 27.98267 \\
\hline 2 & 6741.18 & 49.34219 \\
\hline 3 & 1613.52 & 11.81019 \\
\hline Total & 13662.09 & 100 \\
\hline
\end{tabular}

Table 9: LCC_surface texture distribution.

\begin{tabular}{|l|c|c|}
\hline LCC_Drainage & Area (ha) & Area (\%) \\
\hline Miscellaneous & 1484.37 & 10.86487 \\
\hline 1 & 6573.78 & 48.11691 \\
\hline 6 & 5603.94 & 41.01815 \\
\hline Total & 13662.09 & 100 \\
\hline
\end{tabular}

Table 10: LCC_drainage distribution. 


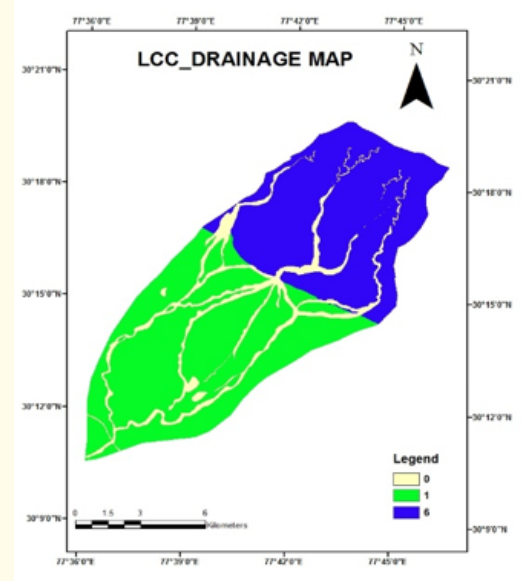

Figure 10: LCC_drainage map.

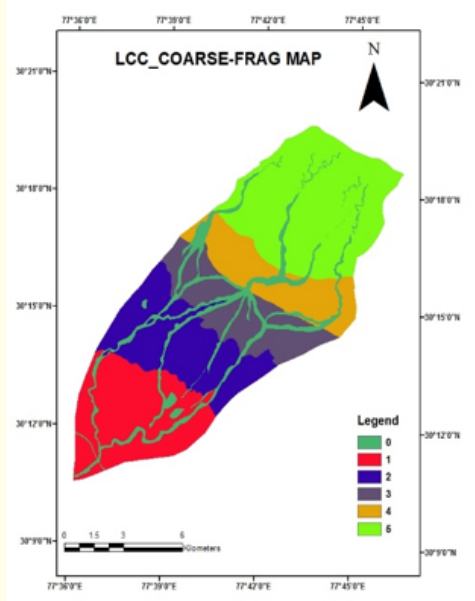

Figure 11: LCC_Coarse_Fragment Map.

\begin{tabular}{|l|c|c|}
\hline LCC_coarse-frag & Area & \% Area \\
\hline Miscellaneous & 1484.37 & 10.86487436 \\
\hline 1 & 2555.01 & 18.70144414 \\
\hline 2 & 2402.37 & 17.58419277 \\
\hline 3 & 1616.4 & 11.83127045 \\
\hline 4 & 1574.64 & 11.52560734 \\
\hline 5 & 4029.3 & 29.49253775 \\
\hline Total & 13662.09 & 100 \\
\hline
\end{tabular}

Table 11: LCC_coarse fragment distribution.

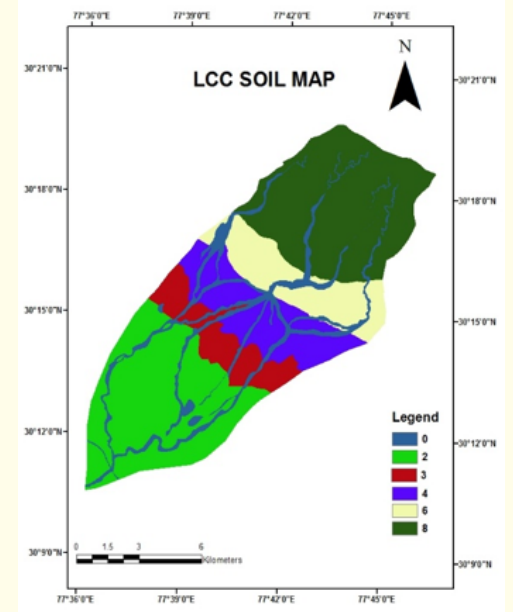

Figure 12: LCC_Soil Map.

\begin{tabular}{|l|c|c|}
\hline LCC_Soil & Area (ha) & Area (\%) \\
\hline Miscellaneous & 1484.37 & 10.87 \\
\hline 2 & 3823.02 & 27.98 \\
\hline 3 & 1134.36 & 8.30 \\
\hline 4 & 1616.4 & 11.83 \\
\hline 6 & 1574.64 & 11.53 \\
\hline 8 & 4029.3 & 29.49 \\
\hline TOTAL & 13662.09 & 100 \\
\hline
\end{tabular}

Table 12: LCC_soil distribution.

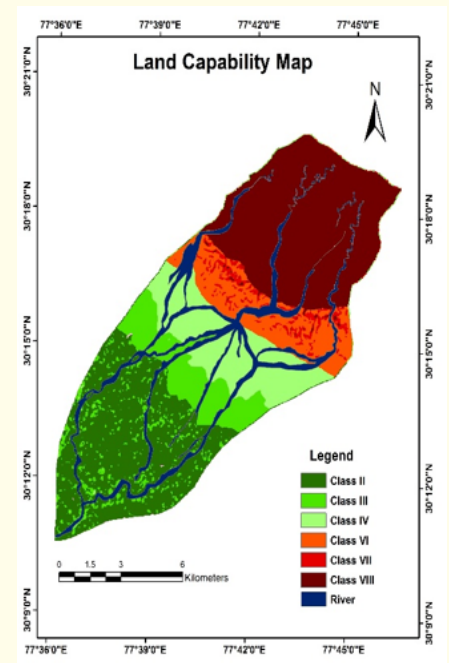

Figure 13: LCC Map. 


\begin{tabular}{|l|c|c|}
\hline LCC & Area (ha) & Area \% \\
\hline 1 & 3.51 & 0.028662 \\
\hline 2 & 3415.05 & 27.88618 \\
\hline 3 & 1602.9 & 13.08876 \\
\hline 4 & 1625.04 & 13.26954 \\
\hline 6 & 1236.69 & 10.0984 \\
\hline 7 & 303.21 & 2.475913 \\
\hline 8 & 4059.99 & 33.15255 \\
\hline Total & 12246.39 & 100 \\
\hline
\end{tabular}

Table 13: LCC Distribution.

\section{Conclusion}

This study was conducted to evaluate soils from India using FAO framework and GIS-based approach, with view to assess and develop a land management strategy for the areas.

Land use and land cover map was prepared with the help of satellite image and six main land use/land covered were identified viz: dense forest, degraded forest, agric I, agric II, scrub and barren land. Total eight physiographic soils unit were identified with the help of LULC, aspect and slope classes. Soil depth generally varies from shallow to deep soil while soil texture varies from sandy loam to coarse sandy loam.

The study area was placed under land capability classes II, III, IV, VI and VIII for soils while integration of LCC-Soil and Slope finally placed the soils in seven classes (I, II, III, IV, VI, VII and VIII). The very steep slopes come under VI, VII and VIII while piedmont and alluvial soils came under classes I, II, III and IV. Land capability evaluation using GIS approach also place the soils from India under classes I, II, III, IV, VI, VII and VIII. This showed that GIS is a useful tool to integrate spatial and non-spatial data obtained from field and it can be used to prepare thematic maps. The study revealed that soils from the study areas varied with different physiographic unit, therefore soils of the hilly areas of India should be put to use for nature conservation other than arable production while the lower portion should be cultivated with intensive care for arable crops.

\section{Acknowledgment}

I acknowledge the Indian Government through the Centre for International Cooperation in Science for the INSA JRD-TATA Fellowship Award given me to undergo 3 months training at Indian
Institute of Remote Sensing (IIRS), Dehradun. I appreciate the Indian Institute of Remote Sensing, Dehradun to give opportunity to be accepted for this work. Special thanks to Doctor Suresh Kumar, and Mr. Justin George for their expert guidance during this training.

\section{Bibliography}

1. Ahmed HR and Fabio T. "Introducing a new parametric concept for land suitability assessment". International Journal of Environment Science and Development 4.1 (2013).

2. Aksoy E., et al. "Soil Mapping Approach in GIS Using Landsat Satellite Imagery and DEM Data". African Journal of Agricultural Research 4 (2009): 1295-1302.

3. Blum WEH. "Soil Resources - The basis of human society and the environment". Bodenkultur 57 (2006): 197-202.

4. De la Rosa D and Van Diepen C. "Qualitative and quantitative land evaluation”. In Verheye W (ed.): Encyclopedia of Life Support System (EOLSS-UNESCO), Section 1.5. Land use and land cover. Eolss Publisher, Oxford (2002).

5. Lal R. "Tillage Effects on Soil degradation, Soil resilience, Soil quality and sustainability". Soil Tillage Research 27 (1994): 1-8.

6. Moore ID., et al. "Soil Attribute Prediction Using Terrain Analysis". Soil Science Society of America Journal 57 (1993): 443452.

7. Thapinta A and Hudak PF. "Use of Geographic Information System for assessing groundwater pollution potential of pesticides in central Thailand". Environmental International 29 (2003): 87-90.

\section{Assets from publication with us}

- Prompt Acknowledgement after receiving the article

- Thorough Double blinded peer review

- Rapid Publication

- Issue of Publication Certificate

- High visibility of your Published work

Website: www.actascientific.com/

Submit Article: www.actascientific.com/submission.php Email us: editor@actascientific.com

Contact us: +919182824667 